\title{
Government Policy on Legal Protection of Household Workers
}

\author{
Suria Ningsih ${ }^{2}$, Erna Herlinda ${ }^{2}$ and Agusmidah ${ }^{3}$ \\ \{suria.ningsih@usu.ac.id $\left.{ }^{1}\right\}$ \\ Fakultas Hukum, Universitas Sumatera Utara, Indonesia ${ }^{123}$
}

\begin{abstract}
The study was conducted to see on how Government policies in providing legal protection to domestic workers through the Minister of Manpower Regulation No. 2 of 2015 concerning Protection of Domestic Workers. In developing countries like Indonesia, domestic workers occupy a fairly large position, even though informal work is always synonymous with lack of protection, low wages, no old age security and no pension, and even no guarantee of work continuity. This type of research is juridical normative by collecting secondary data in the form of primary, secondary and tertiary legal materials through library research. The data were analyzed qualitatively. The results showed that through the Regulation of the Minister of Manpower of the Republic of Indonesia No. 2 of 2015 concerning the Protection of Domestic Workers, the term domestic helper or babu changes its name to become a domestic worker and the term employer changes the name to user. In addition, this Minister of Manpower Regulation requires users or employers and domestic workers to make a written or oral work agreement that contains rights and obligations that can be understood by both parties and known by the Chairman of the Rukun Tetangga or by other names in the area where the domestic worker is. it will work. The work agreement explains the rights and obligations of each party which aims to provide legal certainty and protection for both parties. Users can recruit prospective domestic workers directly or through the domestic worker agency (LPPRT). The agency for distributing domestic workers is a business entity that is required to have a business license for the Agency for the Distribution of Domestic Workers (SIU - LPPRT) and has obtained a written permit from the Governor.
\end{abstract}

Keywords: Legal Protection; Domestic Workers; Minister of Manpower Regulation

\section{Introduction}

Legal protection is providing protection to human beings who have been harmed by others, and this protection is given to the community so that they can enjoy all the rights provided by law or in other words, legal protection is a variety of legal measures that must be provided by law enforcement officials to give a sense of safe, both physically and mentally from the disturbance of various threats from any party. Legal protection is not only for the community in general, but also for workers in particular, including domestic workers (PRT). Often domestic workers are not considered a profession, so the fulfillment of their rights is often only based on the mercy or generosity of the user (employer). Even normatively, domestic workers are not considered a profession because the activities of domestic workers are not the same as those of companies. 
This is because domestic workers work for the user (employer) and are very private, so that each domestic worker has different rules applied by the user or employer, and must comply if you want to work for a long time and stay afloat. Domestic workers often work all day without a clear break time, because they work not only in the household sector, but all the very complex work they do to take care of the employer's child.

In addition, domestic workers in carrying out their work are not regulated in legal norms like formal workers, because there is no supervision from the authorized agency, and there is no work agreement agreed by both parties. If seen from the above conditions, domestic workers (PRT) often experience problems, namely the problem of low wages below the minimum wage and also often their wages are not paid.

Domestic workers also do not have supporting facilities in terms of security, health, work safety, the right to vacation, leave, and are also prone to physical violence and human rights violations. If we respond to this, it is clear that domestic workers do not get legal protection that guarantees their work the same as their colleagues who work in factories, companies, and others. 2 Law No. 13 of 2003 concerning Manpower defines a worker or laborer in article 1 number 3 is everyone who works and receives wages or other forms of remuneration3. Based on the above definition, it appears that domestic workers should be included in the definition of formal sector workers who are protected by law.

Legal protection for domestic workers can only be implemented if there is a clear legal basis to enforce domestic workers and make them workers in a juridical sense, especially placing domestic workers in a work agreement to have the same position as the user or employer. When seen in plain view, legal protection for domestic workers is very weak and often causes many problems, among others, users or employers can arbitrarily terminate employment (PHK) unilaterally just because they are incompetent at work, are sick, and so on. without giving severance pay to domestic workers, whether they are domestic workers who live in the user's house (employer) or come home early in the evening.

Therefore, it is necessary to have public recognition of domestic workers as formal workers, through government actions, so that domestic workers obtain their rights according to or equal to formal workers. It is hoped that the state's concern can guarantee the protection of the basic rights of domestic workers, not the other way around by employing domestic workers who are transferred from individuals to individuals or users or employers without being based on legal regulations. One concrete form of the presence of a legal protection policy for domestic workers is regulated in the Minister of Manpower Regulation No. 2 of 2015 concerning Protection of Domestic Workers. For this reason, it is interesting to see how Government policies regulate Legal Protection for Domestic Workers.

\section{Reference Review}

According to the Big Indonesian Dictionary (KBBI), policy is a series of concepts and principles that outline and plan for the implementation of a job, leadership and how the government acts. According to Woll (1966) public policy is a government activity to solve a problem in society either directly or through various institutions that influence people's lives. Policy in practice has 2 (two) meanings, namely:

a. Policy in the sense of freedom, which is on a particular subject (or the equivalent of the subject). To have an alternative that is accepted as the best based on the values of living together or a certain country in the use of certain powers that exist on the subject in 
overcoming human problems in relation to living together in that country. In other words, policy is the scope of certain freedom in taking alternatives that are accepted as the best based on the values of a certain society or country in overcoming human problems in a series of living together or a certain country and a certain place.

b. Policy in the sense of leaving, is to solve human problems in relation to living together or a certain country, as a result of the use of freedom of choice which is accepted as the best based on the values of living together or a certain country. In other words, a way out in overcoming human problems which is meant as a result of freedom to choose as the best in a time and place based on the values of a particular society or country. 4

Policy objectives are the satisfaction or tranquility and interests of policy makers and decision makers in relation to the satisfaction or tranquility and interests of those subject to the policy, namely the people. In a democratic country, the people are the holders of sovereignty. Thus, administrative policy is aimed at the people and in the interests of the people because state administration exists or is held in the interests of the people. Policy based on morality or law. Policy is always related to accountability, meaning that the policy should ideally be accounted for both morally and legally.

The purpose of formulating or making public policies is to create order, tranquility, peace and welfare of society. This is in line with the concept of a welfare state (walfare state) which is mostly adopted by countries in the world today. In carrying out government policies, there are three sources of government authority, namely attribution, delegation and mandate. Attribution is the granting of governmental authority by legislators to government organs. The formation of legislation carried out by either the original legislators (originaire wetgevers) or the legislators represented (gedelegeerde) gave power to a government organ that was formed on that occasion or to an existing government organ.

Delegation is the transfer of government authority from a government agency or official to another government agency or official. After the authority is handed over, the authorized person has no more authority. The authority obtained through attribution or delegation can be mandated to a subordinate agency or employee if the official who obtains the authority is unable to do so on his own.

E. Utrecht, state administrative powers in the field of legislation include:

a. The authority to make regulations on one's own initiative, especially in the face of precarious situations where there are no regulations without depending on the central legislature.

b. The government is given the task of adjusting the regulations made to events that actually occur in society.

Ministerial Regulation is a type of regulation set by the minister. The existence of a new Ministerial Regulation is recognized and has binding legal force as long as it is ordered by a higher-level regulation or is established based on authority6. As the highest public policy, the implementation of this Ministerial Regulation is further regulated by the Governor and becomes a reference for all other public policies at the regional level.

The term domestic worker is not found directly in the provisions of Law no. 13 of 2003 concerning Manpower. In terms of protection of domestic workers, Law No. 13 of 2003 does not specifically protect and stipulate standard rights for workers in Indonesia who are defined as someone who works and receives wages and or other forms of remuneration. When viewed from the contents of the law, domestic workers should be protected under the Manpower Act, but in reality, we find the opposite (Article 1 Number 3 of the Manpower Act).

Various workers' rights which are the basic rights of workers that apply to workers in general should be assigned to domestic workers. This means that the protection of domestic 
workers' rights must be fulfilled in every work relationship. Starting from the existing manpower laws, it appears that this law has not provided justice and protection to domestic workers.7

Law was created as a means or instrument to regulate the rights and obligations of legal subjects.8 According to Sudikno Mertokusumo, law functions as a protection for human interests. In order for human interests to be protected, laws must be enforced. Therefore, domestic workers must be protected by their rights as people who work day and night by users or employers.

In view of the working hours, not all domestic workers have the same working hours, so the wages or salaries of domestic helpers who work not staying overnight or staying at the user's or employer's house are not the same as workers who stay overnight or stay at the employer's house, because domestic workers who Work 8 hours a day and do not stay overnight at the user's or employer's house, he should be paid the same wage as a factory worker or laborer in general, while domestic workers whose working hours do not last up to 8 hours and do not live in the user's house, the right to wages is calculated based on the working hours of each day (Minister of Manpower Regulation No.13 of 2012).

\section{Research Method}

The approach to the problem used in this research is normative juridical. The normative juridical approach is legal research which is carried out by examining library materials or secondary data as the basic material for research by conducting a search of statutory regulations and literatures relating to the problems under study. 9 The secondary data used is in the form of 3 legal materials, namely primary legal materials, namely binding legal materials originating from the 1945 NRI Constitution, Law Number 13 Year 2003 concerning Manpower, Law No.12 of 2011 concerning the Formation of Regulations. Legislation, Law no. 23 of 2014 concerning Regional Government, Minister of Manpower Regulation No.2 of 2015 concerning Protection of Domestic Workers.

Secondary legal materials, legal materials that provide an explanation of primary legal materials in the form of books, literature, papers, legal dictionaries related to the material coupled with data search activities using the internet and tertiary legal materials that provide additional explanations.

The data collection method is done through library research. Furthermore, the collected data will be processed through the stages of data selection, data classification and data systematization. The data analysis was done qualitatively and continued with inductive conclusion.

\section{Legal Protection for Domestic Workers Based on the Minister of Manpower Regulation No. 2 of 2015}

In Indonesia, the right to work is a basic right of every human being (Article 27 paragraph (2) of the 1945 Constitution of the Republic of Indonesia): Every citizen has the right to work and a decent living for humanity", even convinced as a human right (Article 28 D paragraph (2) The 1945 Constitution of the Republic of Indonesia): Everyone has the right to work and to receive fair and proper compensation and treatment in working relations". 
From the two articles above, the constitutional foundation is strong enough for Indonesia's reasons for making protection regulations for its citizens regardless of the type of work in order to get a decent job and a living from that work, including domestic workers (PRT)

Domestic helpers (PRT) are not covered by the protection of the labor law, they are categorized into the non-formal / informal economic sector. This is different from workers who are in the formal sector, such as workers who work in industrial sectors which are protected by labor laws. Domestic servants are considered not to be employed by "employers"; they are not given the protection afforded by the labor law to other workers. This arises because the legal concept in the Manpower Act itself does not regulate non-formal employment relationships.

In fact, workers who do non-formal jobs feel that they are included in the concept of workers / laborers in Article 1 point 3 of the manpower law, namely every person who is capable of doing work to produce goods and / or services either to fulfill their own needs or to fulfill their needs. Public. Relations between domestic workers and their employers are generally only regulated based on trust, in contrast to the work relations mechanism in the formal sector which also provides a dispute resolution mechanism in industrial relations courts.

The legal concept developed in Law no. 13 of 2003 concerning Manpower places a recognized work agreement between a worker and an employer (not a company), see Article 14. However, in the provisions related to rights and obligations that must be implemented regarding the normative rights of workers / labor, only employers with the category of employer are obliged to do so. For example, the provisions concerning the right to work time and rest time, starting from articles 77 to 85 , are only aimed at employers, not other employers. So, it is clear that for domestic workers whose employer is the individual employer, this provision does not apply. And so, on including K3, wages, social security and severance pay.

Imam Soepomo10 detailing the coverage of labor protection in three ways, namely:

a. Economic protection, namely protection of workers in the form of sufficient income, including if the worker does not work against his will.

b. Social protection, namely protection of workers in the form of occupational health insurance and freedom of association and protection of the right to organize.

c. Technical protection, namely protection of workers in the form of security and safety.

Work protection is manifested in a legal field, namely labor law, and is now increasingly popular with the term labor law. The background of the emergence of this legal field is due to the fact that the parties involved in the work relationship are in an unbalanced position. O. Kahn Freund11 states that the emergence of the Manpower Law is due to the inequality of the bargaining position that exists in the employment relationship (between workers / laborers and employers / employers) on the grounds that it can also be seen that the main objective of the Manpower Law is to eliminate the imbalance of the relationship between the two.

H. Sinzheimer12 it even affirms that an employment agreement is said to be valid when the agreement between the two parties is only a "voluntary compliance" with conditions that have been determined unilaterally by the employer / employer. Such are the views that emerge from the reality of the work relationship where one party has a higher position and vice versa is lower than one another. This view strengthens the support of the authorities (the state) to neutralize inequality for the protection of work for the parties, thus the regulation of laws and regulations is an instrument that creates this situation.

Based on the foregoing and to cover the legal vacuum with regard to the protection of domestic workers, the Minister of Manpower Regulation No. 2 of 2015 concerning Protection 
of Domestic Workers which is a reference for Regional Governments to make further regulations regarding the protection of domestic workers as Article 28 states that the implementation of this Ministerial Regulation is further regulated by the Governor.13

In the legal considerations of this Ministerial Regulation, it is stated that in order to provide protection to domestic workers, it is necessary to regulate the Agency for the Distribution of Domestic Workers, basic protection and empowerment for domestic workers while respecting local customs, culture and customs. Furthermore, efforts to provide protection to domestic workers cannot be separated from the participation of users of domestic workers to provide domestic workers' rights as agreed by the parties.

This Minister of Manpower Regulation consists of IX-chapter 30 Article which contains general provisions, work agreements between users and domestic workers, requirements, rights and obligations of domestic workers, requirements, rights and obligations of users, requirements for domestic workers channeling institutions, terms and procedures for making SIU-LPPRT including obligations. and prohibition of the Agency for the Distribution of Domestic Workers. At the end of this Ministerial Regulation also regulates Guidance and Supervision of LPPRT and administrative sanctions that can be imposed if there is a violation of this provision.

Article 1 Regulation of the Minister of Manpower No. 2 of 2015 contains, among others:

a. Domestic Worker, hereinafter referred to as PRT, is a person who works for an individual in the household to carry out household work by receiving wages and / or other forms of remuneration.

b. Domestic work is work that is carried out within the scope and interests of the household

c. Domestic Worker User, hereinafter referred to as User, is an individual who employs domestic workers by paying wages and / or other forms of remuneration

d. Domestic Worker Agency, hereinafter referred to as LPPRT, is a business entity that has received a written permit from the Governor or an appointed official to recruit and distribute domestic workers.

e. Business Permit for Domestic Worker Agency, hereinafter abbreviated as SIU-LPPRT, is a permit issued by the Governor or appointed official to recruit and distribute domestic workers employed to users.

f. Minister is the Minister of Manpower

Article 2 of this Regulation states that users can recruit domestic workers directly or through LPPRT. At present, domestic workers are no longer based on kinship, but because of skill factors, so that the domestic worker supplier industry has developed. The objective of this Ministerial Regulation is to provide protection to domestic workers while respecting local customs, culture and customs. To become a domestic worker must meet the following requirements; Have an identity document, at least 18 (eighteen years old) and obtain permission from husband / wife for domestic workers who are married (article 4). From this article, it can be seen that this regulation prohibits the employment of minors, by providing a minimum age limit for domestic workers. In addition, a partner's permission is needed, showing that this regulation really respects the institution of marriage by trying to maintain the integrity of a family.

Before carrying out work, domestic workers should enter into a work agreement. This is the first step taken before a work relationship takes place, so the work agreement must be implemented properly and correctly. This in turn will provide justice for both the user or employer as well as for domestic workers or domestic workers, because both will be involved in an employment relationship. We can see this provision in Article 5 of the Minister of 
Manpower Regulation which states that users and domestic workers are required to make a written or oral work agreement that contains rights and obligations and can be understood by both parties and known by the Chairman of the Rukun Tetangga or by other names. The existence of provisions known to the Rukun Tetangga is necessary because the RT is the responsible party in the environment, can also carry out supervision on behalf of the community and is likely to become a mediator if one day a dispute occurs between users and domestic workers considering the unbalanced position of the parties.

Article 6 explains that the contents of the work agreement must contain; the identity of the parties, the rights and obligations of the parties, the period of validity of the work agreement, the place and date the work agreement was made. The work agreement is valid for a period of 2 (two) years and can be extended or terminated according to the agreement of both parties. As for the rights of domestic workers are: (Article 7)
a. Obtain information about Users
b. Get good treatment from users and their family members
c. Get wages according to the work agreement
d. Get healthy food and drinks
e. Get adequate rest time
f. Get the right to leave in accordance with the agreement
g. Get the opportunity to perform worship in accordance with the religion and belief
h. Get holiday allowances

Communicating with his family; In addition, domestic workers also have obligations (article 8), namely:

a. Carry out duties and responsibilities in accordance with the Work Agreement

b. Finish a job well

c. Maintain ethics and courtesy in the User's family

d. Notifying the User within sufficient time if the domestic worker will stop working

Until now, the existence of domestic workers has not been recognized by all parties as the same workforce as workers in factories, companies, and others. Even today, the community still considers domestic workers as helpers. Therefore, domestic workers are included in the scope of informal work16. Likewise, the Minister of Manpower Regulation No. 2 of 2015 does not specify rights as workers such as standardization of wages, arrangements for working hours and rest periods, weekly, annual leave, the right to communicate and associate as well as written and non-verbal agreements.

Rights that are often violated are the right to wages, the right to limit working hours, the right to rest, the right to vacation, the right to leave the house, the right to communicate, the right to organize, the right to humane treatment, and the right to get social security. This phenomenon is inversely proportional to the 1945 Constitution Article 28D Paragraph 2 which states that everyone has the right to work and to receive fair and proper compensation and treatment in an employment relationship. In the context of legal protection for domestic workers, it is very important, especially if it is seen that the scope of work of domestic workers is very complex if the domestic worker resides or lives in the same house as the user or employer. This results in psychological relationships, social relationships mixed with work relationships.

This Ministerial Regulation also regulates the rights and obligations of users, namely: User Rights 17 including: obtaining information about domestic workers, obtaining domestic workers who are able to work well, getting good work results namely: 
a. Paying wages according to the work agreement

b. Provide healthy food and drinks

c. Providing adequate rest rights to domestic workers

d. Provide the opportunity to perform worship in accordance with the religion and belief

e. Giving holiday allowances once a year

f. Give the right to leave in accordance with the agreement

g. Participating in social security programs

h. Treat domestic workers well

i. To report the use of domestic workers to Rukun Tetangga or other names

Furthermore, in chapter IV of this Permenaker, the Agency for the Distribution of Domestic Workers is regulated. If you look at this Permenaker, it actually regulates more about LPPRT. This can be seen in more than half of the articles regulating LPPRT, namely from article 12 to article 27. In the first consideration of this regulation, it is stated that in order to provide protection to domestic workers it is necessary to regulate the Agency for the Distribution of Domestic Workers, basic protection and empowerment for domestic workers while respecting local customs and traditions.

From this, it can be seen that the focus of this Permenaker is regulating the existence of the LPPRT as an institution that plays a role in the recruitment of these domestic workers. Through the existence of the LPPRT, the government wants to provide protection to domestic workers. Efforts to provide protection to domestic workers cannot be separated from the participation of domestic workers to provide domestic workers' rights as agreed by the parties.

In order to control and supervise LPPRT, this Permenaker requires LPPRT that will distribute domestic workers to have SIU-LPPRT from the Governor or an appointed official (Article 12). To obtain SIU-LPPRT as intended, LPPRT must submit an application in writing by attaching it:

a. Copy of deed of establishment and / or deed of change of business entity which has been approved by the competent authority

b. A copy of the articles of association that contains activities engaged in the distribution of domestic workers

c. Copy of company domicile certificate

d. Copy of Taxpayer Identification Number (NPWP)

e. Copy of proof of ownership of office facilities and infrastructure as well as own office equipment

f. Organizational and personnel structure chart

g. Minimum work plan for 1 (one) year,

Then all files will be verified. If it is complete within 2 (days) of work, the official concerned must issue SIU-LPPRT. The management of SIU-LPPRT is free of charge (Article 15 ) and the validity period of this SIU-LPPRT is 5 (five) years and can be extended for a maximum period of 5 (five) years. Applications for the extension of SIU-LPPRT are submitted no later than 30 (thirty) days before the expiration of the validity period. If the LPPRT does not extend the SIU-LPPRT, then the LPPRT is obliged to return the original SIU-LPPRT to the official concerned (Article 17). The application for the extension of SIULPPRT is submitted in writing to the Governor or the appointed official by attaching:

a. Copy of valid SIU-LPPRT

b. Proof of submission of reports on the number of domestic workers who have been distributed. 
c. Domestic workers plan to be distributed for at least 1 (one) year, and

d. Copy of proof of ownership of office facilities and infrastructure as well as own office equipment.

Furthermore, all the provisions that apply to the issuance of SIU-LPPRT also apply equally to this SIU_LPPRT extension19. In the event of a change in the name of the business entity, address or person in charge, the LPPRT must submit a written request for a change in SIU-LPPRT by attaching:
a. Copy of valid SIU-LPPRT
b. Deed of change of business entity which has been approved by the competent authority
c. Proof of submission of reports on the number of domestic workers who have been distributed
d. LPPRT work plan to distribute domestic workers for at least 1 (one) year
e. Copy of proof of ownership of office facilities and infrastructure as well as own office equipment.

What's interesting about this Minister of Manpower Regulation is the provision that LPPRT is prohibited from collecting fees from domestic workers but is entitled to receive fees from users, the amount of which is determined based on the agreement between the LPPRT and the User20. This is a form of protection provided by the government to domestic workers. Minister of Manpower Regulation No. 2 of 2015 concerning Protection of Domestic Workers also regulates the obligations of the LPPRT,21 namely:
a. Select potential users
b. Ensure that prospective domestic workers are in good health and can work well
c. Monitor domestic workers who have been distributed to users
d. Return the service fee that has been received from the user if the domestic worker is not willing to continue working for at least 6 (six) months.

This provision shows that this ministerial regulation not only protects domestic workers but also users through the obligations given to LPPRTs. In addition to regulating the LPPRT's obligations, there is also a prohibition against LPPRT, namely it is prohibited to distribute domestic workers to corporate users or business entities or other entities that are not individuals 22 because for this there are other rules governing it. Article 25 mentions the LPPRT's obligation to submit reports every month to the Governor or the appointed official, the number and data of domestic workers being distributed, then the Governor or appointed official reports to the minister every 6 (six) months, the number of LPPRTs, the number and data of domestic workers in their region23. All of this is intended for administrative control.

With regard to the guidance and supervision of the LPPRT, it is carried out by the Governor or the appointed official, in this case the Provincial Manpower Office which includes:
a. Data collection on the number of LPPRTs and the number of domestic workers who were distributed
b. lection on the number of LPPRTs and the number of domestic workers who were distributed, Licensing control and LPPRT performance evaluation
c. LPPRT licensing services through an online system that can be accessed by the public
d. Strengthening the level of supervision to the neighborhood level in the framework of fostering and preventing cases of violence against domestic workers


e. Giving administrative sanctions to LPPRT who violate the provisions stipulated in this Ministerial Regulation.

The administrative sanctions referred to are in the form of a written warning, temporary suspension of part or all of LPPRT's business activities and license revocation. Furthermore, this Ministerial Regulation mandates the Governor to make further regulations for its implementation25. The LPPRT that existed before the enactment of this Ministerial Regulation is obliged to comply with the provisions stipulated in this Ministerial Regulation no later than 1 (one) year from the enactment of this Ministerial Regulation26

\section{Conclusion}

To cover the legal vacuum with regard to the protection of domestic workers that has not been regulated in Law no. 13 of 2003 concerning Manpower and as a form of the presence of the state in protecting its citizens as mandated by Article 27 paragraph 2 of the 1945 Constitution of the Republic of Indonesia has issued Regulation of the Minister of Manpower No. 2 of 2015 concerning Protection of Domestic Workers which is a reference for Regional Governments to make further regulations regarding the protection of domestic workers as Article 28 states that the implementation of this Ministerial Regulation is further regulated by the Governor.

This Minister of Manpower Regulation consists of IX-chapter 30 Article which contains general provisions, work agreements between users and domestic workers, requirements, rights and obligations of domestic workers, requirements, rights and obligations of users, requirements for domestic workers channeling institutions, terms and procedures for making SIU-LPPRT including obligations. and prohibition of the Agency for the Distribution of Domestic Workers. At the end of this Ministerial Regulation also regulates Guidance and Supervision of LPPRT and administrative sanctions that can be imposed if there is a violation of this provision. It is hoped that through this regulation, a policy with regard to protection for domestic workers will be born, which as long as there is no regulation, even though domestic workers are a noble job and an integral part of national development.

\section{References}

[1] Darmoyo,Syarief \& Rianto Adi,2004, Tfficking Anak Untuk Pekerja Rumah Tangga, PKPM Unika Atmajaya

[2] HR. Ridwan, 2017, Hukum Administrasi Negara, Rajawali Press, Jakarta Jurnal Hukum Samudra Keadilan Vol. 12

[3] Kay, Geoffrey and James Mott, 1982, Political Order and The Law of Labour, The Macmillan Press Ltd, London

[4] Killpatrick, Claire, 2003, Has New Labour Reconfigured Employment Legislation?.

[5] Industrial Law Journal, vol. 32, No.3, September

[6] Ningsih, Suria, 2011. Mengenal Hukum Ketenagakerjaan, USU Press, Medan

[7] 24 Ibid, Pasal 27

[8] 25 Ibid,Pasal 28

[9] 26 Ibid,Pasal 29

[10] Soekanto, Soejono \& Sri Mamudji, 2001. Penelitian Hukum Normatif ( Suatu Tinjauan Singkat), Rajawali Pres, Jakarta

[11] Soepomo, Imam, 1995, Pengantar Hukum Perburuhan, Djambatan., Jakarta 
[12] Voll, Willy D.S. ,2013, Dasar-Dasar Ilmu Hukum Administrasi Negara, Sinar Grafika, Jakarta

[13] Wahyono, Padmo, Politik Hukum,

[14] Wedderburn,Lord, 2000, Collective Bargaining or Legal Enactment : The 1999 Act and Union Recognition, Industrial Law Journal, Vol.29, No.1, Maret

[15] http://id.wikipedia. org/pekerjarumahtangga 9 Februari 2020 www.tesishukum.com

[16] Undang-Undang Dasar NRI Tahun 1945

[17] Undang-Undang No.13 Tahun 2003 Tentang Ketenagakerjaan

[18] Undang-Undang No. 12 Tahun 2011 Tentang PembentukanPeraturan Perundang-undangan

[19] Peraturan Menteri Ketenagakerjaan RI No. 2 Tahun 2015 Tentang Perlindungan Pekerja Rumah Tangga 